\title{
Short Communication: Acute toxicity study of plantaricin from Lactobacillus plantarum S34 and its antibacterial activity
}

\author{
ARIDO YUGOVELMAN AHADDIN ${ }^{1, \bullet}$, SRI BUDIARTI ${ }^{2}$, A. ZAENAL MUSTOPA ${ }^{3, \bullet \bullet}$, HUDA S. DARUSMAN $^{4}$, \\ LITA TRIRATNA ${ }^{3}$ \\ 1School of Biotechnology, Institut Pertanian Bogor. Jl. Raya Dramaga, Bogor 16680, West Java Java, Indonesia. Tel./fax.: +62-251-8622642, \\ vemail: a.yugovelman@gmail.com \\ 2Research Center for Bioresource and Biotechnology, Institut Pertanian Bogor. Jl. Raya Dramaga, Bogor 16680, West Java Java, Indonesia \\ 3Research Center for Biotechnology, Indonesian Institute of Sciences. Jl. Raya Jakarta-Bogor Km. 46, Cibinong, Bogor 16911, West Java, Indonesia, \\ Tel./fax.: +62-21-8754587, »email: azmustopa@yahoo.com. \\ 4Departement of Physiology, Pharmacology and Toxicology, Faculty of Veterinary Medicine, Institut Pertanian Bogor.Jl. Agatis, Kampus IPBDarmaga, \\ Bogor 16680, West Java, Indonesia
}

Manuscript received: 23 July 2020. Revision accepted: 20 December 2020.

\begin{abstract}
Ahaddin AY, Budiarti S, Mustopa AZ, Darusman HS, Triratna L. 2021. Short Communication: Acute toxicity study of plantaricin from Lactobacillus plantarum S34 and its antibacterial activity. Biodiversitas 22: 227-232. Lactobacillus plantarum S34 belongs to the Lactobacilli class produces a bacteriocin called plantaricin. Bacteriocins are well known as active compounds that inhibit bacterial growth. This study was conducted to determine the antimicrobial activity of plantaricin S34 and its safety profile in the ddY mouse animal models. Plantaricin 34 from the crude extract was identified using Tricine SDS-PAGE. Antimicrobial activity was observed using disk diffusion against EPEC K1.1, S. aureus, S. typhosa, S typhimurium, and Proteus sp. The safety assessment showed that crude extract of plantaricin S34 did not cause any abnormalities to experimental mice even after being administrated with 5000 $\mathrm{mg} / \mathrm{kg} \mathrm{BB}$. The identification of plantaricin S34 showed an active molecule at $7.34 \mathrm{kDa}$ and had an activity to inhibit the pathogens used in this study. The blood analysis showed that the hematological and biochemical blood properties were in the normal range. Histopathological examination showed no damage to the intestine, liver, and kidneys. Thus, the crude extract of plantaricin S34 is active as an antimicrobial agent without any toxicity effects.
\end{abstract}

Keywords: Antibiotics, bacteriocin, Lactobacillus plantarum, plantaricin, toxicity

Abbreviations: AMPs: Antimicrobial peptides, AST: Aspartate transaminase, ALT: Alanine transaminase, LAB: Lactic Acid Bacteria, MDR: Multiple drug-resistant, PCV: Packed cell volume

\section{INTRODUCTION}

Multiple drug-resistant (MDR) has been a major problem to date. MDR leads to a decrease in the efficacy of drugs against bacterial infections. According to WHO (2017), 12 types of bacteria are MDR. Several studies have been conducted to find alternative active compounds such as lytic phage (Budiarti et al. 2011) and natural compounds like antimicrobial peptide (Arief et al. 2015, Hanny et al. 2019). Antimicrobial peptides are naturally produced by individual organisms to kill threatened bacteria. The antimicrobial activity possessed by AMPs is almost the same as that of broad-spectrum antibiotics. It can be used against Gram-positive and Gram-negative bacteria, viruses, fungi, and parasites (Dosler and Mataraci 2013). This ability makes bacteriocin a potential alternative to substitute antibiotics.

Lactic acid bacteria (LAB) are a group of Grampositive bacteria that produce a bacteriocin. Lactic acid bacteria are naturally found in processed milk or fermented food. Some of the LAB genera are known to have antimicrobial, antifungal, or antioxidant activity, i.e.
Lactobacillus, Lactococcus, Streptococcus, Leuconostoc, Pediococcus, Bifidobacterium, and Propionibacterium (Utami 2011). A study by Utami (2011) showed that Lactobacillus plantarum was the most developed bacteria reported to produce plantaricin with antimicrobial properties.

Plantaricin is an exoprotein produced by Lactobacillus plantarum, classified as class II bacteriocin. Class II bacteriocin is a non-lantibiotic peptide with low molecular weight, heat resistance, and extensive modification (Ekblad et al. 2016). Plantaricin inhibits Candida albicans (Sharma and Srivastava 2014), Listeria innocua NRLL B33314, Micrococcus luteus MTCC 106, Enterococcus casseliflavus NRRL B3502, Lactococcus lactis NRRL 1821 Lactobacillus curvatus NRRL B4562, and Lactobacillus plantarum NRRL B4496 (Pal et al. 2014). A study on plantaricin S34 in Indonesia was initiated by isolating $L b$. plantarum S34 from bekasam, a traditional Indonesian fermented food (Mustopa 2013). On the genetic level, identification of the plantaricin gene showed that plantaricin S34 pln gene encodes plantaricin EF (Mustopa et al. 2016) and W (Umami et al. 2017). The encoded plantaricin gene transformed into Lactococcus lactis, and 
the presence of each peptide was evaluated. The recombinant protein of plantaricin can inhibit Entherophatogen Escherichia coli, both in vitro and in vivo (Hanny et al. 2019). Hanny et al. (2019) recommended that Lb. plantarum S34 is a remarkable candidate for antibiotic replacement. Thus, to address those issues above, we evaluate the antimicrobial activity of plantaricin S34 in vitro and its safety in vivo using the animal model of the ddY mice.

\section{MATERIALS AND METHODS}

\section{Materials}

Materials used in this study were ammonium sulfate (Merck, Denmark), agarose (Himedia, India), de Man Rogosa Sharpe Broth (Himedia, India), Luria Bertani (Himedia, India), Hematoxylin-Eosin, formalin 4\%, ethanol absolute (Merck, Denmark), xylol, paraffin, glycerin 99.5\%, $\mathrm{NaCl}$ (Merck, Denmark), and TCA, TBA, BHT, Tris- $\mathrm{HCl}$ (Vivantis, USA).

\section{Microorganism}

Lactobacillus plantarum S34 was obtained from Biotechnology Laboratory, Indonesian Institute of Sciences (LIPI), Cibinong, Bogor, West Java, Indonesia. The inoculum was stored in de Man Rogosa Sharpe broth media at $4^{\circ} \mathrm{C}$. Isolate bacteria $(S$. aureus, $S$. typhosa, $S$. typhimurium, and Proteus sp.) were obtained from LIPI collection (Indonesia culture collection/Ina-CC) cultured in Luria Bertani media. EPEC K1.1 bacteria were obtained from the Animal Biotechnology Laboratory, Bogor Agricultural University, Bogor, Indonesia and were cultured in nutrient broth media.

\section{Procedures}

This study is carried out in three steps; the first step is to identify plantaricin S34 in the LAB growth media using Tricine SDS-PAGE. The second step is to analyze the activity of identified plantaricin S34 against tested bacteria, such as EPEC K1.1, S. aureus, S. typhosa, S typhimurium, and Proteus $s p$ due to their MDR profile. The last step was to evaluate the safety of the crude extract of plantaricin S34 using the mouse animal model. As a new candidate for antibiotics, it is necessary to determine the safety of plantaricin S34 to ensure that no abnormalities will occur during treatment.

\section{Production of Plantaricin S34}

Lactobacillus plantarum S34 was isolated from bekasam using serial dilution methods in saline solution and plated onto MRS agar (Oxoid, England). The plates were incubated at $37{ }^{\circ} \mathrm{C}$ for $2 \mathrm{~d}$, and then a single confirmed colony was used afterward. Plantaricin S34 was produced following the method by Ekbald et al. (2016). Lactobacillus plantarum S34 was cultured in MRS medium and incubated overnight at $37^{\circ} \mathrm{C}$. After the incubation, $L b$. plantarum was centrifuged at $10000 \times \mathrm{g}$ at $4^{\circ} \mathrm{C}$ for $30 \mathrm{~min}$. The supernatant was collected and adjusted with $0.1 \mathrm{~N}$ $\mathrm{NaOH}$ until $\mathrm{pH}$ 6.5. The supernatant was precipitated with
$60 \%\left(\mathrm{NH}_{4}\right)_{2} \mathrm{SO}_{4}$ at $4{ }^{\circ} \mathrm{C}$ overnight. The pellet was collected by centrifugation at $10000 \times \mathrm{g}$ at $4^{\circ} \mathrm{C}$ for 30 minutes, then resuspended in Tris $\mathrm{HCl}$ buffer $\mathrm{pH} 7.4$.

\section{Identification of Plantaricin S34 using Tricine SDS- PAGE and zymograms}

The identification of plantaricin was performed in Tricine Sodium Dodecyl Sulfate Polyacrylamide gel (Tricine SDS-PAGE) at a concentration of 4\% (stacking gel) and $16 \%$ (separating gel) (Haider et al. 2012). Polyacrylamide gel is made by mixing acrylamide: bisacrylamide (29:1), aqua dest, glycerol, TEMED, and ammonium persulfate. The gel was stained using a silver stain (Thermo Fisher, USA). The zymograms were done by placing the gel above agar media, which contains $10^{6}$ EPEC K1.1 bacteria. The gel was fixated using $25 \%$ ethanol and 5\% formaldehyde for 30 minutes, then washed using sterilized water for three $h$. It was rewashed three times using Tween-80 for $40 \mathrm{~min}$ before placing it to pathogens media, then incubated at $37^{\circ} \mathrm{C}$ for $24 \mathrm{~h}$.

\section{Antibacterial activity test}

Antibacterial activity was carried out by the agar diffusion method (Arief et al. 2015). The tested bacteria were cultured on LB for $16 \mathrm{~h}$ and diluted with physiological $\mathrm{NaCl}$ until the concentration reaches $10^{6}$ $\mathrm{CFU} / \mathrm{mL}$. The bacteria were incubated on Luria Bertani agar (LA) at $37^{\circ} \mathrm{C}$ for $16 \mathrm{~h}$, then a clear zone was measured.

\section{Experimental animals preparation}

A total of 30 male ddY mice (15-30 g BW) were obtained from the Experimental Animal Laboratory Biofarma, Bandung. The adaptation period was seven days before the starting experiment. Mice were kept in plastic boxes with feed and drinking water available ad libitum. Light at the housing room was set to $12 \mathrm{~h}$ light-dark periods at $20^{\circ} \mathrm{C}$. The experimental animals were divided into several groups using simple random sampling. Each group consists of five mice. This study has ethical approval from Bogor Agricultural University Ethics Commission with ethics number 80-2017IPB.

\section{Acute toxicity of Plantaricin S34 crude protein}

The toxicity assay was done by following the method of Almeida Vaucher et al. (2011). Male ddY mice aged 4-8 weeks were kept in a group with standard food and drink. There are six treatment groups. Plantaricin S34 was administrated once orally to each group using 50, 100, 1000 , and $5000 \mathrm{mg} / \mathrm{kgBW}$. The clinical symptoms (skin and fur, eyes, lethargy, convulsions (seizures), tremors (trembling), diarrhea, and death) were observed at 2, 12, 24 , and $48 \mathrm{~h}$ post-treatment. Bodyweight measurement was done every $24 \mathrm{~h}$. After $48 \mathrm{~h}$ post-treatment, mice were euthanized (exsanguination), then the blood, liver, and kidney were collected for further analyses.

\section{Hematology analysis}

The hematology analysis was done by following Aboderin and Oyetayo's (2016) methods. Hematology 
parameters include PCV, hemoglobin, erythrocytes, leucocytes, and thrombocyte) using hematology analyzer Hemavet HV950FS (Drew Scientific Inc, German).

\section{Biochemical analysis}

Biochemical analysis of the blood was carried out as follows: blood was centrifuged at $6000 \times \mathrm{g}$. The serum was separated from the blood cells. The serum was tested for biochemical parameters (AST, ALT, urea, and creatinine) using hematology analyzer Hemavet HV950FS.

\section{Histopathological analysis}

Histopathological analyses were performed using Schmitz et al. (2010) methods: the collected tissue was fixed in $10 \%$ buffer formalin and processed for paraffin embedding. The histological sections were stained with hematoxylin-eosin. The slides were coded and analyzed at the Primate Study Center, Bogor Agricultural University, Bogor, Indonesia.

\section{Data analysis}

The results were expressed as mean \pm standard deviation of the groups and subjected to analysis of variance and Tukey's test using software Minitab 17.0. The differences were considered statistically significant when $\mathrm{p}$ $<0.05$.

\section{RESULTS AND DISCUSSION}

\section{Identification and antimicrobial activity of plantaricin S34}

Plantaricin S34 was obtained using a $60 \%$ precipitation of ammonium sulfate. The concentration of crude plantaricin S34 was $66 \mathrm{mg} / \mathrm{mL}$. The molecular identification using Tricine SDS-PAGE showed the presence of two bands lower than ten $\mathrm{kDa}$ at positions approximately $7.34 \mathrm{kDa}$ (upper arrow) and $5.82 \mathrm{kDa}$ (lower arrow) (Figure 1). The zymograms showed that the 7.34 $\mathrm{kDa}$ band has activity against EPEC K1.1 while the 5.82 $\mathrm{kDa}$ band has no activity.

Antimicrobial activity of crude plantaricin S34 against several pathogens was shown in Table 1. The crude plantaricin S34 has better antibacterial activity against $S$. aureus and EPEC K1.1 but has a different activity to the other pathogens.

\section{Plantaricin S34 Safety in ddY mice}

The administration of plantaricin crude extract did not cause any changes in clinical observation (data not shown). The control group has slightly increased body weight while the treatment groups were decreased (Figure 2B). The bodyweight of treatment groups was not significantly different compared to the control group. The weight of organs (heart, kidney, brain, liver, spleen, and lungs) was also not significantly different from control (Figure 2A).

The treatment of plantaricin S34 resulted in decreased leucocyte and PCV levels. Plantaricin administration resulted in increased thrombocyte and erythrocyte. The decrease of leucocytes level increases with the higher the given concentration. The leucocyte was lowered from 3.10 thous $/ \mu \mathrm{L}$ to 1.95 thous $\mu \mathrm{L}$. The decrease in leucocytes was contrasted to the PCV level, which shows a fluctuation depends on the given doses. The highest level of PCV was observed in plantaricin treatment at the concentration of 50 $\mathrm{mg} / \mathrm{kg} \mathrm{BW}$, while the lowest PVC level was in the treatment of $100 \mathrm{mg} / \mathrm{kg} \mathrm{BW}$. The highest level of thrombocytes and erythrocytes were 524.67 \pm 43.25 thous $/ \mu \mathrm{L}$ and $8.93 \pm 0.03 \mathrm{mill} / \mu \mathrm{L}$, respectively. The lowest level of thrombocytes and erythrocytes were $378.00 \pm 26.06$ thous $/ \mu \mathrm{L}$ and $35.03 \pm 1.97 \mathrm{mill} / \mu \mathrm{L}$, respectively. These values were significantly different compared to control (Table 2). The normal amount of leukocytes ranges from 1.5 to 4.8 thous $/ \mu \mathrm{L}$; thrombocytes range from 325 to 888 thous $/ \mu \mathrm{L}$, and erythrocytes range from 6.1 to $10.7 \mathrm{mill} / \mu \mathrm{L}$, and PCV ranges from 33.5 to $47.8 \%$ (Santos et al. 2016).

Blood serum analysis was also performed to determine the effect of plantaricin S34 on liver and kidney performance. Table 3 showed that plantaricin treatment increased urea, creatinine, AST, and ALT levels. The increasing level of each component was not correlated. The administration of $1000 \mathrm{mg} / \mathrm{kg}$ BW plantaricin S34 increases most of the blood serum parameters. There was a significant difference in all observed components compared to control.

There were no abnormalities cause by plantaricin administration in hepatocytes and central venous cells (Figure 2F), kidney cells, tubules, and glomerulus (Figure $2 \mathrm{E}$ ). Observation of mice intestinal sections showed no damage to the small villous intestine (Figure 2D).

Table 1. Antimicrobial activity of plantaricin S34

\begin{tabular}{lcc}
\hline \multirow{2}{*}{ Pathogen } & \multicolumn{2}{c}{ Clear zone (mm) } \\
\cline { 2 - 3 } \multicolumn{1}{c}{ Ampicillin } & Plantaricin S34 \\
\hline EPEC K1.1 & $1.5 \pm 0.29$ & $6 \pm 0.82$ \\
S. aureus & $12 \pm 0.41$ & $7 \pm 0.32$ \\
S. typhimurium & $18 \pm 0.00$ & $4 \pm 0.96$ \\
Proteus sp. & $13.5 \pm 1.25$ & $4 \pm 0.50$ \\
\hline
\end{tabular}

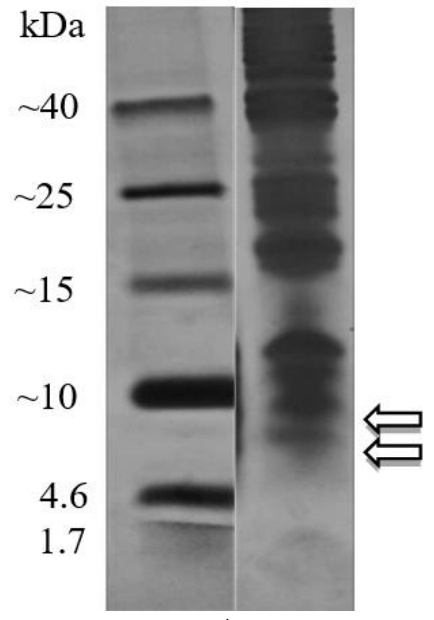

A

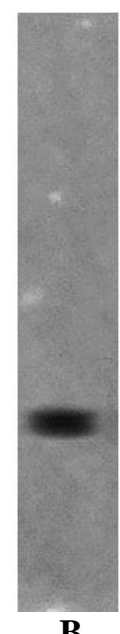

B
Figure 1. Separation of plantaricin S34 using Tricine SDSPAGE(A) and zymograms (B) 


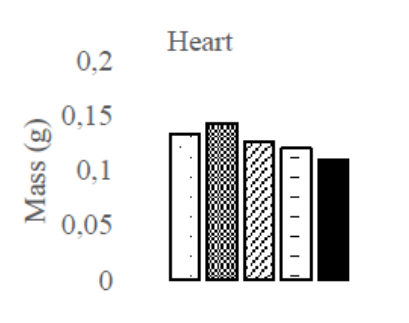

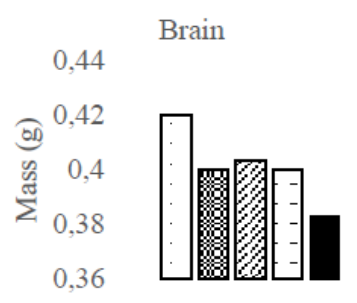

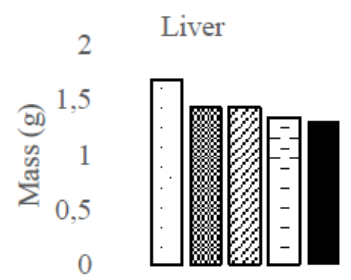

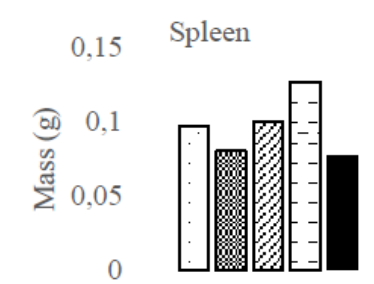

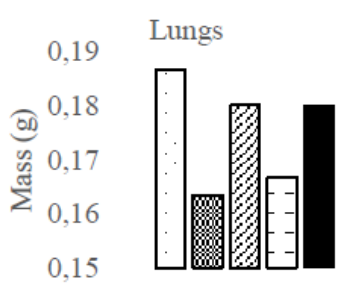

$\square$ Control $\square 5000 \square 1000 \square 100 \square 50$

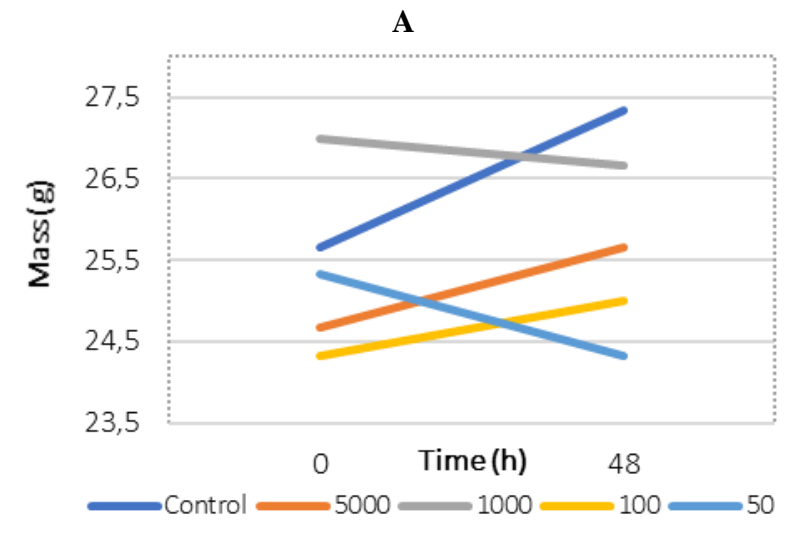

B

Figure 2. Effect of plantaricin S34 crude protein administration on the mass of: A. Several organs, B. Bodyweight
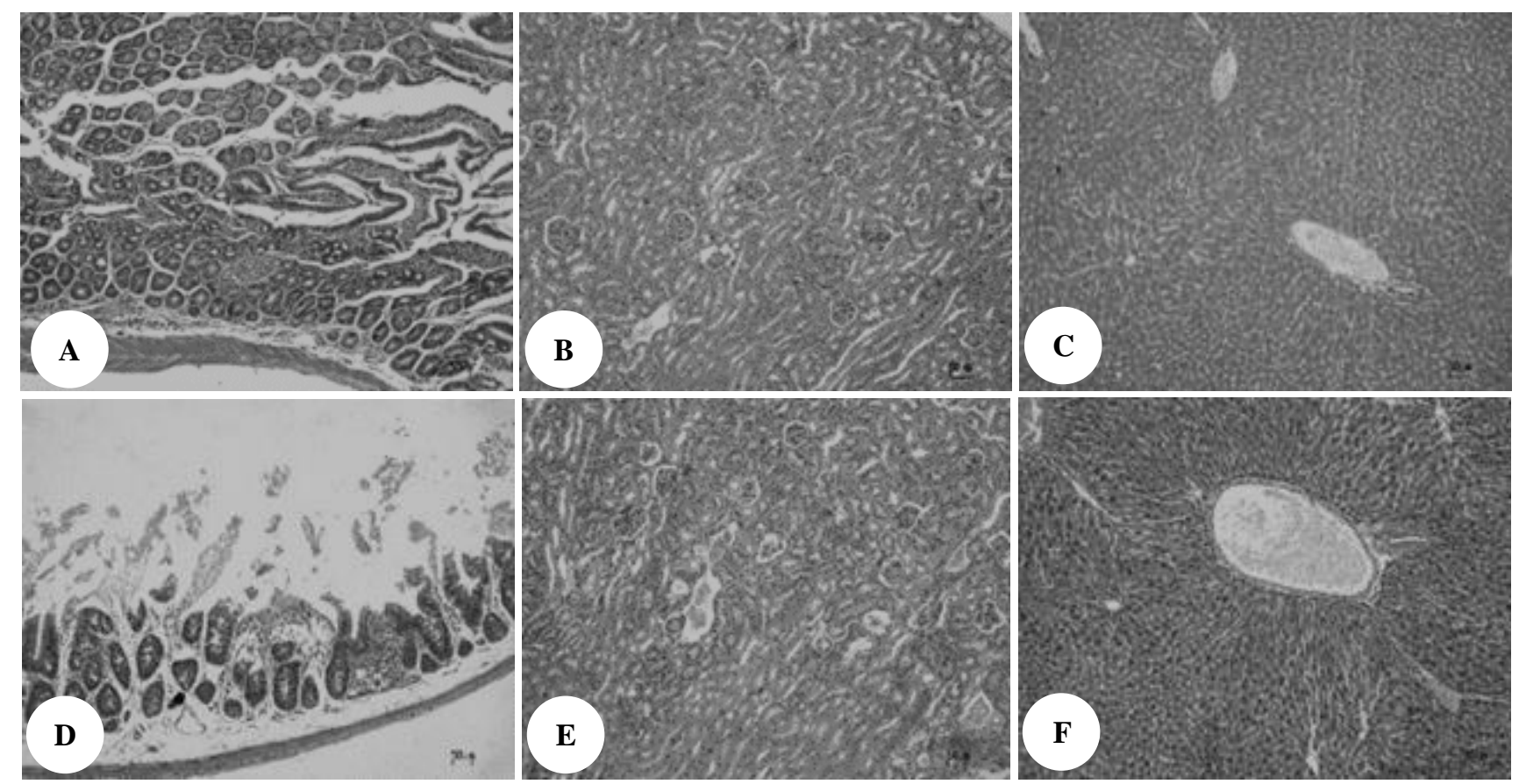

Figure 3. A. Photomicrographs of intestine section; B. Kidney section; and C. Liver section of control group. D. Histopathological observation of intestine section, E. Kidney section, and F. Liver section of mice treated with $5000 \mathrm{mg} / \mathrm{kg} \mathrm{BW}$. 
Table 2. Hematological parameters of the ddY mice $48 \mathrm{~h}$ after plantaricin S34 administration

\begin{tabular}{lccccc}
\hline Groups & Hemoglobin $(\mathbf{g} / \mathbf{d L})$ & Leucocyte (thous/ $\boldsymbol{\mu L})$ & Thrombocyte (thous/ $\boldsymbol{\mu L})$ & Erythrocyte $(\mathbf{m i l l} / \boldsymbol{\mu L})$ & PCV $(\%)$ \\
\hline Kontrol & $12,73 \pm 1.31^{\mathrm{a}}$ & $3,10 \pm 0.10^{\mathrm{a}}$ & $473,33 \pm 15.31^{\mathrm{a}}$ & $7,02 \pm 0.64^{\mathrm{a}}$ & $34,93 \pm 3.23^{\mathrm{a}}$ \\
NaCl & $11.05 \pm 0.31^{\mathrm{a}}$ & $1.50 \pm 0.20^{\mathrm{b}}$ & $451.00 \pm 39.74^{\mathrm{a}}$ & $7.10 \pm 0.47^{\mathrm{a}}$ & $34.13 \pm 1.35^{\mathrm{a}}$ \\
S34 5000 & $12.60 \pm 0.10^{\mathrm{a}}$ & $1.95 \pm 0.53^{\mathrm{bc}}$ & $378.00 \pm 26.06^{\mathrm{b}}$ & $8.30 \pm 0.22^{\mathrm{b}}$ & $40.73 \pm 0.55^{\mathrm{b}}$ \\
S34 1000 & $13.43 \pm 0.59^{\mathrm{a}}$ & $2.20 \pm 0.10^{\mathrm{c}}$ & $466.00 \pm 8.54^{\mathrm{a}}$ & $8.58 \pm 0.28^{\mathrm{b}}$ & $42.00 \pm 2.19^{\mathrm{b}}$ \\
S34 100 & $12.00 \pm 1.35^{\mathrm{a}}$ & $2.10 \pm 0.85^{\mathrm{bc}}$ & $524.67 \pm 43.25^{\mathrm{a}}$ & $6.49 \pm 0.13^{\mathrm{a}}$ & $35.03 \pm 1.97^{\mathrm{a}}$ \\
S34 50 & $13.13 \pm 0.78^{\mathrm{a}}$ & $2.30 \pm 0.10^{\mathrm{c}}$ & $436.67 \pm 65.96^{\mathrm{a}}$ & $8.93 \pm 0.03^{\mathrm{b}}$ & $44.63 \pm 2.69^{\mathrm{b}}$ \\
\hline
\end{tabular}

Note: *The number shared the same character have no significant result with $\mathrm{P}<0.05$

Table 3. Effect of plantaricin S34 administration on some serum biochemical parameters in ddY mice

\begin{tabular}{lcccc}
\hline Groups & Ureum $(\mathbf{g} / \mathbf{d L})$ & Creatinin $(\mathbf{g} / \mathbf{d L})$ & AST $(\mathbf{U} / \mathbf{L})$ & ALT $(\mathbf{U} / \mathbf{L})$ \\
\hline Control & $46.67 \pm 8.14^{\mathrm{a}}$ & $0.39 \pm 0.03^{\mathrm{a}}$ & $207.25 \pm 74.43^{\mathrm{a}}$ & $52.33 \pm 1.15^{\mathrm{a}}$ \\
$\mathrm{NaCl}$ & $85.33 \pm 5.51^{\mathrm{b}}$ & $0.43 \pm 0.02^{\mathrm{a}}$ & $250.00 \pm 37.47^{\mathrm{a}}$ & $80.33 \pm 7.77^{\mathrm{b}}$ \\
S34 5000 & $80.67 \pm 3.06^{\mathrm{b}}$ & $0.65 \pm 0.06^{\mathrm{b}}$ & $230.67 \pm 36.67^{\mathrm{a}}$ & $83.87 \pm 7.76^{\mathrm{b}}$ \\
S34 1000 & $95.33 \pm 10.41^{\mathrm{b}}$ & $0.53 \pm 0.08^{\mathrm{b}}$ & $395.00 \pm 92.07^{\mathrm{b}}$ & $128.67 \pm 26.10^{\mathrm{c}}$ \\
S34 100 & $61.67 \pm 1.15^{\mathrm{d}}$ & $0.45 \pm 0.04^{\mathrm{a}}$ & $304.00 \pm 31.19^{\mathrm{a}}$ & $64.33 \pm 4.93^{\mathrm{d}}$ \\
S34 50 & $90.67 \pm 1.53^{\mathrm{bc}}$ & $0.41 \pm 0.03^{\mathrm{a}}$ & $288.00 \pm 42.58^{\mathrm{a}}$ & $131.33 \pm 20.21^{\mathrm{c}}$ \\
\hline
\end{tabular}

Note: *The number shared the same character have no significant result with $\mathrm{P}<0.05$

\section{Discussion}

The identified protein in Tricine SDS-PAGE was predicted as two types of class II bacteriocin based on molecular weight. The low molecular weight determined from Tricine SDS-PAGE was suspected as plantaricin S34. Zymogram data described that plantaricin S34 only has one active band, which is $7.34 \mathrm{kDa}$.

Plantaricin can inhibit bacterial growth through the mechanism of electrolyte efflux, disrupt membrane potential (Zhang et al. 2015), and inhibit the 14- $\alpha$ demethylase enzyme (Omar and Yadav 2018). Plantaricin S34 crude protein has better activity than ampicillin in inhibiting EPEC K1.1. Budiarti (2011) reported that EPEC $\mathrm{K} 1.1$ has resistances against ampicillin compared to other bacteria. The presence of plantaricin S34 crude protein activity against pathogens makes this compound has potencies to substitute antibiotic.

All mice groups that received plantaricin S34 treatments showed significant differences in levels of leukocytes, platelet, erythrocytes, and PCV. However, these changes are still at the normal levels for each component. . Plantaricin S34 is a protein that is easily degraded by proteolytic enzymes. The residue of degraded plantaricin S34 did not cause elevation of hematological profile to exceed the normal range.

Blood serum analysis was performed to determine the effect of plantaricin S34 on the liver and kidney. The increment of ureum level in the blood level indicating that plantaricin S34 can be digested by enzymes and converted to amino acids and ammonia. Besides, urea levels are influenced by protein consumption, protein digestion in the digestive tract, muscle protein degradation as well as creatinine levels that are related to muscle mass, body metabolism, infection, or inflammation (Martono and Satino 2014).
AST and ALT changes are related to the secretion of protease enzymes in the liver. It can be caused by protein consumption, activity, damage to body cells, or infection. Tissue damage or liver disorders can be indicated by an increase of 5-15 times from the normal level. The use of drugs that risk to generate liver disorders can increase the ALT/AST activity up to $\geq 20$ times from normal activity (Aleya and Berawi 2015).

Observation of liver cells showed normal hepatocytes and central venous cells (Figure $2 \mathrm{~F}$ ). The observations on the kidney section did not show any abnormalities in kidney cells, tubules, or glomerulus (Figure 2E). Observation of mice intestinal sections showed no damage to the epithelium or small villous (Figure 2D). However, observation of intestinal sections showed a slight infiltration of mononuclear inflammatory cells. The low damage caused by the administration of plantaricin S34 at a dose of $5000 \mathrm{mg} / \mathrm{kg} \mathrm{BW}$ indicates that this substance is safe to be used for short terms used.

We conclude that plantaricin S34 is an exoprotein with molecular weight of $7.34 \mathrm{kDa}$. Plantaricin S34 could inhibit the growth of EPEC K1.1, S. typhi, S. typhosa, S. aureus, and Proteus sp. Hematological and biochemical analysis of blood showed that plantaricin S34 administration increases those parameters but was still in the normal range. The histopathological analysis showed no abnormalities in the kidney, liver, and intestine sections. Thus, our results support that plantaricin, particularly plantaricin S34 is a candidate for substituting antibiotics.

\section{ACKNOWLEDGEMENTS}

This research was funded by the National Innovation System Research Incentive (INSINAS) program of the 
Ministry of Research, Technology, and Higher Education in the 2016-2017 fiscal year.

\section{REFERENCES}

Aboderin F, Oyetayo VO. 2006. Haematological studies of rats feed different doses of probiotic, Lactobacillus plantarum, isolated from fermenting corn slurry. Pak J Nutr 5: 102-105.

Aleya A, Berawi K. 2015. Korelasi pemeriksaan laboratorium SGOT/SGPT dengan kadar bilirubin pada pasien hepatitis $\mathrm{C}$ di ruang penyakit dalam RSUD Dr. H. Abdul Moeloek Provinsi Lampung pada Bulan Januari-Desember 2014. Jurnal Majority 4: 135-139. [Indonesian]

Almeida Vaucher R de, Velho Gewehr CCV, Correa APF, Sant'Anna V, Ferreira J, Brandelli A. 2011. Evaluation of the immunogenicity and in vivo toxicity of the antimicrobial peptide P34. Int J Pham 421 (1): 94-98.

Arief II, Budiman C, Jenie B, Andreas E, Yuneni A. 2015. Plantaricin IIA-1A5 from Lactobacillus plantarum IIA-1A5 displays bactericida activity against Staphylococcus aureus. Beneficial Microb 6: 603613.

Budiarti S. 2011. Antibiotic resistance Escherichia coli isolated from faecal of healthy human. J Intl Environ Appl Sci 6: 359-364.

Budiarti S, Pratiwi RH, Rusmana I. 2011. Infectivity of lytic phage to enteropathogenic Escherichia coli from diarrheal patients in Indonesia. J US-China Med Sci 8: 273-282.

Dosler S, Mataraci E. 2013. In vitro pharmacokinetics of antimicrobial cationic peptides alone and combination with antibiotics against methicillin resistant Staphylococcus aureus biofilm. Peptides 49: 5358.

Ekbald B, Kyriakou PK, Oppegard C, Nissen-Meyer J, Kaznessis YN, Kristiansen PE. 2016. Structure-function analysis of the two-peptide bacteriocin plantaricin EF. Biochemistry 55: 5106-5116.

Haider SR, Reid HJ, Sharp BL. 2012. Tricine-SDS-PAGE. In: Kurien BT, Scofield RH (eds.) Protein Electrophoresis, Methods in Molecular Biology. Springer Sciense+Business Media, Springfield.

Hanny ELL, Mustopa AZ, Budiarti S, Darusman HS, Ningrum RA, Fatimah. 2019. Efficacy, toxicity study, and antioxidant properties of plantaricin $\mathrm{E}$ and $\mathrm{F}$ recombinants against enteropathogenic Escherichia coli K1.1 (EPEC K1.1). Mol Biol Rep 46: 6501-6512.

Martono M, Satino S. 2014. Severity renal function detection through critical changes glomerular filtration rate in hemodialysis patients. Jurnal Ners 9: 43-48. [Indonesian]

Mustopa AZ. 2013. Isolation and Characterization of Lactobacillus plantarum S34 from Indonesian Traditional Food. [Disertation]. Dankook University, Yongin. [South Korea]

Mustopa AZ, Kusdianawati, Fatimah, Umami RN, Budiarto RB, Danuri H. 2016. Cloning and expression of plantaricin $\mathrm{E}$ and $\mathrm{F}$ genes of Lactobacillus plantarum S34 isolated from Indonesian traditionalfermented meat (bekasam). Intl Food Res J 23 (2): 762.

Omar R, Yadav A. 2018.The remarkable cationic peptides: a boon to pharmaceutical science. J Pharma Pharmaceut Sci 21: 60-72.

Pal G, Sheela S. 2014. Cloning and heterologous expression of plnE, -F, -J and $-\mathrm{K}$ genes derived from soil metagenome and purification of active plantaricin peptides. Appl Microbiol Biotechnol 98: 14411447.

Santos EW, Dalila CO, DC de Oliveira, Araceli H, GB da Silva, JS de Oliveira Beltran, Maristela T, Amanda RC, Silvania MPN, Ricardo AF, Primavera B. 2016. Hematological and biochemical reference value for C57BL/6 Swiss Webster and balb/c mice. Braz J Vet Res Anim Sci 53: 138-145.

Schmitz N, Laverty S, Kraus VB, Aigner T. 2010. Basic methods in histopathology of joints tissue. Osteoarthritis Cartilage 18: 113-116.

Sharma A, Srivastava S. 2014. Anti-Candida activity of two-peptide bacteriocins, plantaricins (Pln E/F and $\mathrm{J} / \mathrm{K}$ ) and their mode of action. Fungal Biol 118: 264-275.

Umami RN, Mustopa AZ, Sukmarini L, Danuri H, Putri AS, Wibowo KDA. 2017. Cloning, expression, and partial purification of plantaricin W locus produced by Lactobacillus plantarum S34. Berita Biologi 16: 59-67. [Indonesian]

Utami ER. 2011. Antibiotika, Resistensi, dan Rasionalitas Terapi. Fakultas Sains dan Tekhnologi UIN Maliki, Malang. [Indonesian]

World Health Organization. 2017. Glonal priority list of antibioticresistant bacteria to guide research, discovery, and development of new antibiotics. WHO PPL Short Summary. WHO, Geneva.

Zhang X, Yang W, Lei L, Yunlu W, Nan S, Xiangmei Z, Pinglan L. 2015. Two peptide bacteriocin PlnEF causes cell membrane damage to Lactobacillus plantarum. Biochim et Biophys Acta 1858: 274-280 